\title{
REFURBISHMENT AND EVALUATION OF A TWO-WHEELED TRACTOR
}

\author{
J. N. Nwakaire ${ }^{1,}{ }^{*}$, A. C. Ezeagba ${ }^{2}$, and 0. C. Ogoegbulem ${ }^{3}$ \\ 1, 2, 3, DEPT. OF AGRICULTURAL \& BIORESOURCES ENGINEERING, UNIVERSITY OF NIGERIA, NSUKKA, NIGERIA \\ E-mail addresses:1 joel.nwakaire@unn.edu.ng, 2 anita.ezeagba@unn.edu.ng, \\ 3 ogoegbulemaugstina@gmail.com
}

\begin{abstract}
The refurbishment of GUTBROD-WERKE/80 two-wheeled tractor for better functioning and subsequent field performance evaluation was carried out. Physical and mechanical inspections were done to ascertain the state of the tractor. The observed faults were; rusted and stuck carburetor, damaged induction coil, rusted fuel control, stuck wheels, worn out tires, and no implement attachment base. The faults were corrected by designing coupling flanges for implement attachment; replacement of carburetor and worn-out parts. The tractor was tested by conducting a field evaluation using standard equations and procedure. The results obtained showed that the field efficiency and effective field capacity were $61.50 \%$, and $0.032 \mathrm{ha} / \mathrm{hr}$ respectively. The fuel consumption was $0.43 \mathrm{~L} / \mathrm{hr}$ at a depth and width of cut of $8.94 \mathrm{~cm}$ and $27.46 \mathrm{~cm}$ respectively at an average soil moisture content of $13.2 \%$. The implement draft and drawbar pull were $1.13 \mathrm{kN}$ and $0.43 \mathrm{~kW}$ respectively. The tractor performance shows its suitability for small farm work.
\end{abstract}

Keywords: two-wheel tractor, refurbishment, effective field capacity, field efficiency

\section{INTRODUCTION}

Development of single-axle tractors and power tillers worldwide began in the early 20th century and for many decades involved a mixture of people working independently in local contexts and, in other cases, of people expanding on the inspiration provided by others' work in distant locals, learned about via exports, travel (whether for jobs, business, or military service), or reading (magazines, newspapers, journals). Such countries include; Switzerland, United States, Japan, Thailand, Sri Lanka, India, Bangladesh, China, Germany, Vietnam, United Kingdom, Italy etc. [1].

Farmers quickly found that 2-wheel tractors were more economical to use, as compared to keeping animals for tillage and 2-wheel tractors began selling widely. Agricultural machinery dealers received cattle in exchange for tractors and in turn sold the cattle in the meat market. Average tractor horsepower per hectare in 1950 was nearly zero. This average increased to 0.86 horsepower per hectare within ten years with the rapid spread of two-wheel tractors. Trailer attachments were widely utilized for transportation [2].

The Power Tiller is a multipurpose two wheel tractor designed suitable for use in paddy fields, dry fields, vegetable gardens and hilly land with a little inclination. It can be used for plowing, rotor-tilling and harrowing in paddy fields as well as harvesting, drilling, ditching and transportation [3]. These power tillers can be called "single-axle tractor, walk-behind tractor, and hand tractor according to Sakai [4]. It can also be extensively used as a stationary power source for small scale drainage and irrigation, spraying, grain threshing, cotton ginning, flour milling and feeder cutting [3]. The concept of using power tiller drawn wheeled multipurpose tool carrier was introduced newly as a development of the animal drawn wheeled tool carrier. Though, the initial cost of equipment is slightly high, it offers several advantages like timeliness in farm operation, quality and precision of work, increased work rate, efficient utilization of machine power, reduction in human drudgery and allow for year round use due to its multipurpose utility. The popularity of these models among farmers is limited. The multipurpose tool carrier can be used for different operations like plowing, harrowing, tillage etc. by attachment with suitable implements. The efficient machine management requires accurate performance data on the capability of individual machine in order to meet the projected work and to form balanced mechanization system by matching the performance of separate items of equipment [5]. Safety of using twowheeled tractors is considered low in the area of 
crossing bunds and road accident in line with reports from Shridar et al [1]. The operation of two-wheel tractors for transport at night is a recognized hazard in many countries, particularly as single headlights can be mistaken for a motorcycle [6][7]. Occupational health and safety reports have recommended regular brakes for the machine operator due to vibrations [8].

In all the machinery used in agriculture, it is important to use appropriate technology that matches the country or farmer's specific need [9]. The performance of agricultural machines is assessable by the rate at which an operation is accomplished and by the quality of the output [10]. Field machine task or capacitive performance is the rate at which it can cover a field while performing its intended function or useful work. It is usually measured by the rate of work in hectares per hour [11]. This is in line with matching equipment to task for effective operation. According to Kathirvel et al [12], the ability to provide draft to pull various types of implements is a primary measure of the effectiveness of a tractor. If the power tiller provides such function, then it will be viable for promoting the transition from subsistence to commercial agricultural production [13]. In practice, most of the potential energy is lost in the conversion of chemical energy to mechanical energy, along with losses from the engine through the drive train and finally through the tractive device [14]. The performance of tractor depends on the performance of a combination of traction devices and the performance of the tractor drive train. While the efficiency of a traction device is defined as tractive efficiency, the efficiency of a complete tractor is defined as power delivery [15]. Studies show that lighter tractors perform better on soft soils because the driving force increases proportionally with the driving axle load and travelling resistance increases exponentially with tractor weight. As a consequence, drawbar pull (draft) is less when the tractor is heavy [16]. Also, since drawbar power is a function of draft and speed, observation also shows that lighter tractors gave the highest drawbar power since a large pull and high speed will result in a large drawbar power. Moreover, a research carried out on two- wheeled tractor compared with the standard wheeled tractor on the bases of hourly performance or field time, soil penetration, cost and field yield shows that for all operations, two-wheeled tractor has the best hourly performance for plowing (first and second shallow plowing). Also, in terms of soil preparation and cost, the small tractors were the best (appropriate) [17]. Ayoade and Adetunbi [18] showed that power tiller had higher operating cost than the four wheeled tractors. More so, their result revealed that the field capacity and soil manipulation of four-wheeled tractor is significantly higher than two-wheeled tractor.

According to Haque and Bell [19], successful increase per hectare field cultivated has been positively affected by the increased use of power-tillers in countries like Malaysia, Indonesia and Pakistan. From the foregoing, it is clear that power tillers or fondly called two wheeled tractors are viable alternative for transition from small holder farming to commercial farming. According to Haque et al. [20], power tiller are viable engine power source for Sub-Saharan Africa where big tractors are either costly to maintain and/or to purchase. Therefore, the specific objectives of this study are to refurbish a GUTBROD-WERKE/80 twowheel tractor and test the effectiveness of the tractor in handling tillage operation.

\section{MATERIALS AND METHODS}

In refurbishing the two wheeled tractor, materials were used in order to resuscitate the dilapidated tractor to a working state. Spanners, screwdrivers and pliers of different types and sizes were used in loosening and tightening screws, fixing and removing of hose clips respectively. Thinner, a liquid substance was used to initially service the carburetor before it was finally replaced. Gasoline fuel was employed during servicing of the injection and exhaust system of the carburetor. It was also used to provide energy through combustion of the fuel (internal combustion engine).

Two tractive tires were used to replace the worn out tires to improve the tractor's efficiency in the field. Mould board plow was coupled to the tractor and was used for field operations.

Spark plug was used to supply spark to ignite the fuelair mixture with the help of ignition coil.

Materials employed during field operations include:

Graduated cylinder: used to measure the amount of fuel consumed during field operation.

Graduated rule: used to measure the depth and width of cut.

Stop watch: used for time measurements during field operations.

Measuring tape: used to take the measurement of the field in terms of length and width of the field.

Engine oil: it was mixed with the fuel (gasoline) to aid smooth combustion (2 stroke engine).

\subsection{Inspection of the two-Wheeled Tractor}

After a thorough inspection on the tractor which was parked at the tractor garage of Agricultural and Bioresources Engineering, University of Nigeria, Nsukka for over 26 years according to the farm manager at the University of Nigeria farm yard, the

Vol. 37, No. 4, October, 2018 
following problems were noted; deflated tractive tires, rust carburetor, blocked and stiffened hose, dirty and blocked fuel tank, blocked fuel filter, coupling device not found, spark plug not found, and bad induction coil

\subsection{Identified Point of Correction}

- Need to design a coupling flange because the coupling flange was nowhere to be found.

- Need to design a flange to adapt the new carburetor to the tractor.

- An induction coil with an appropriate timing attachment base.

- Proper placement of fuel control.

\subsubsection{Design of coupling attachment}

\section{Coupling Flange for Implement Coupling}

The coupling flange was fabricated at Agricultural and Bioresource Engineering Fabrication workshop.

Choice of materials: The material chosen for the fabrication of the coupling flange is iron steel due to ease of construction, cost and availability of material.

Engineering drawing: The orthographic (2D) and isometric (3D) drawings are shown in figure 1 . The thickness of the flat metal plate is $12.5 \mathrm{~mm}$. The thickness of the cylindrical part is $12.5 \mathrm{~mm}$

While the inside and outside diameter are $42.02 \mathrm{~mm}$ and $54 \mathrm{~mm}$ respectively. The cylindrical part was welded to the flat plate. The orthographic and isometric drawings are shown in figure 1 and 2 .

\subsubsection{Coupling Flange for Carburetor Coupling}

Choice of material: The material chosen for the fabrication of the coupling flange is iron steel due to ease of construction, cost and availability of material. Figure 3 shows the orthographic (2D) design of the carburetor sitting

\subsubsection{Replacement of PARTS}

Parts replaced are:

1. Induction coil for 2-stroke, 4-cycle engine: The old and new ignition coils are shown in Figures 4 and 5 respectively.

2. Carburetor: The old and new carburetors are shown in Figures 6 and 7 respectively.

3. Traction tires and tube: The old and new tires are shown in Figure 8.

4. The equipment consists of two major parts: the prime mover (power-tiller) and the accompanying implements (moldboard plow). The dilapidated tractor is shown in Figure 9.

\subsection{Experimental Site}

The field operations and performance evaluation of the power tiller were carried out on Agricultural and Bioresource Engineering experimental site behind soil bin facility building of University of Nigeria, Nsukka.

\subsection{Field Layout and Operations}

Only moldboard plowing was carried out on the field and the appropriate implement coupled to the power tiller and used to carry out the corresponding field operation. Area of land covered during the field operation was determined based on resources and time available at the period of the experiment.

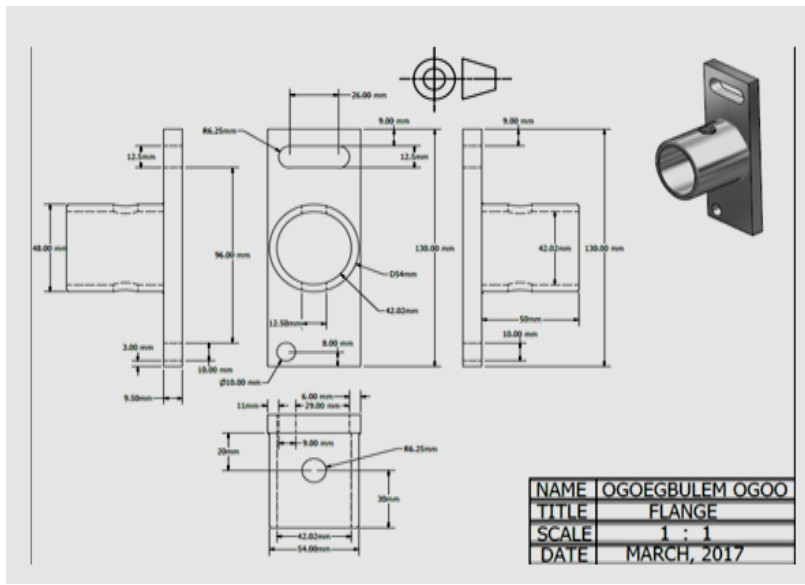

Figure 1: 2D drawing of the coupling flange with dimensions
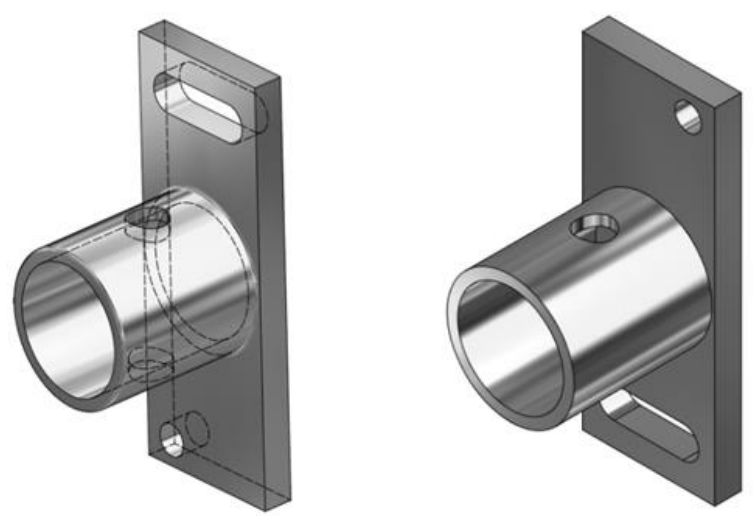

Figure 2: 3D drawing of the coupling flange

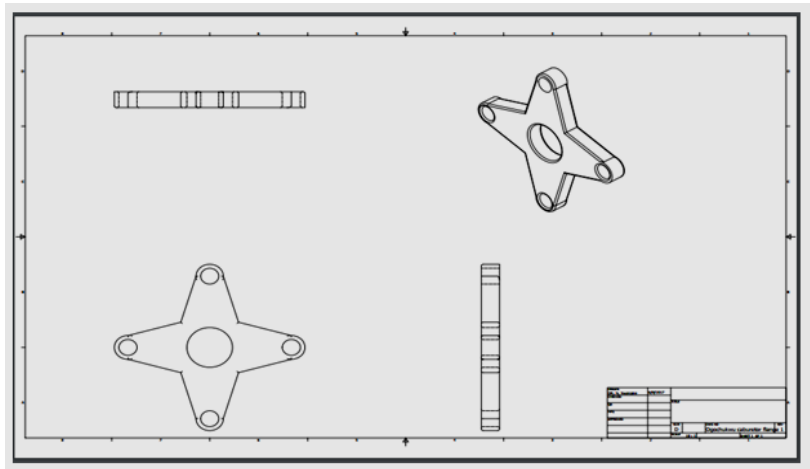

Figure 3: 2D drawing of the carburetor coupling flange. 


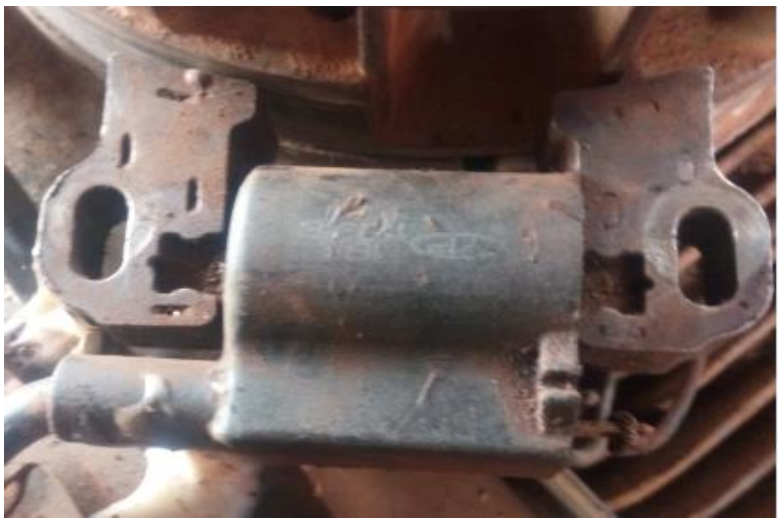

Figure 4: Old ignition coil

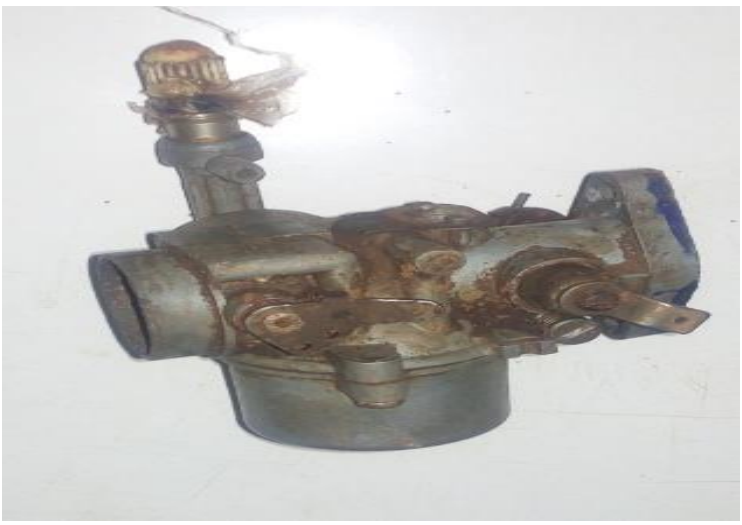

Figure 6: Old carburetor

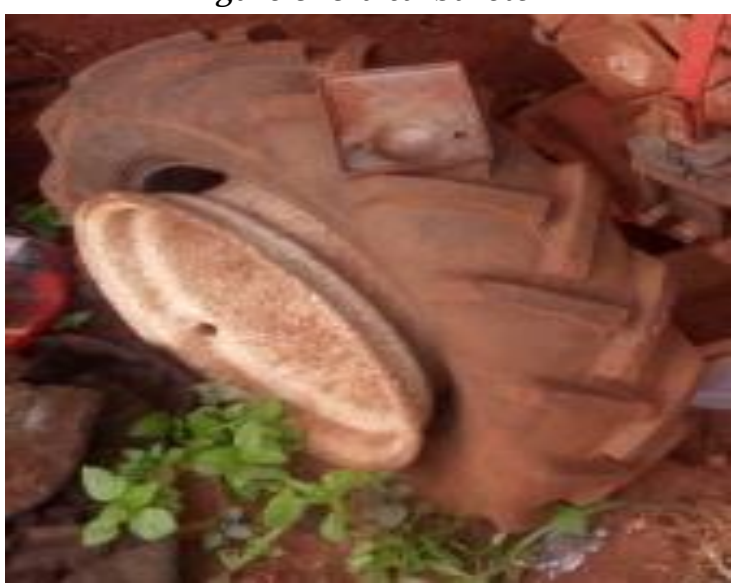

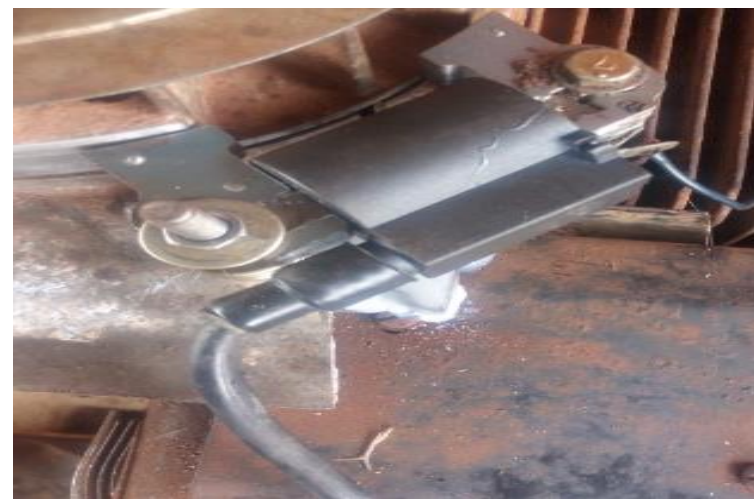

Figure 5: new ignition coil with fittings

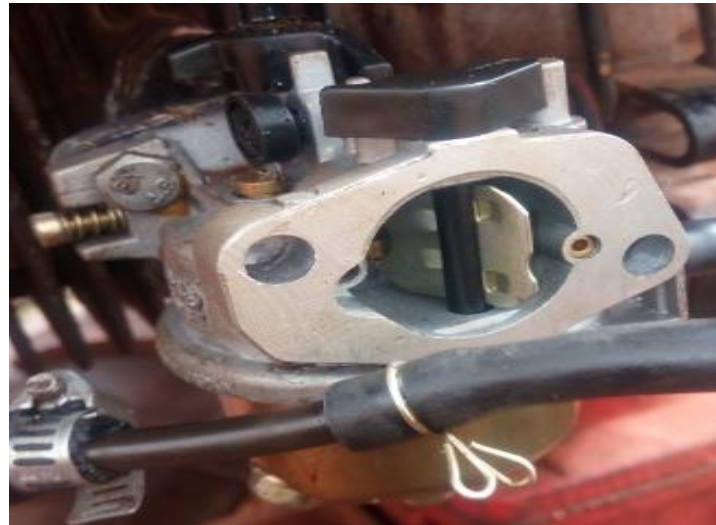

Figure 7: New carburetor

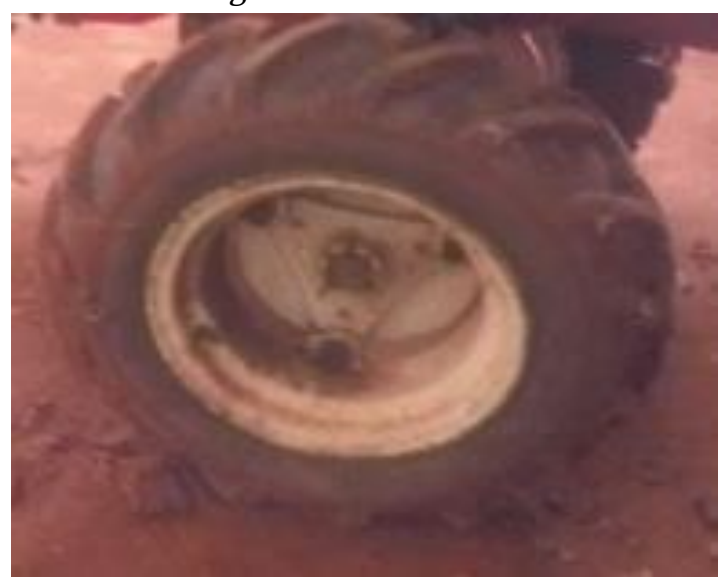

Figure 8: Deflated tires and the new tires
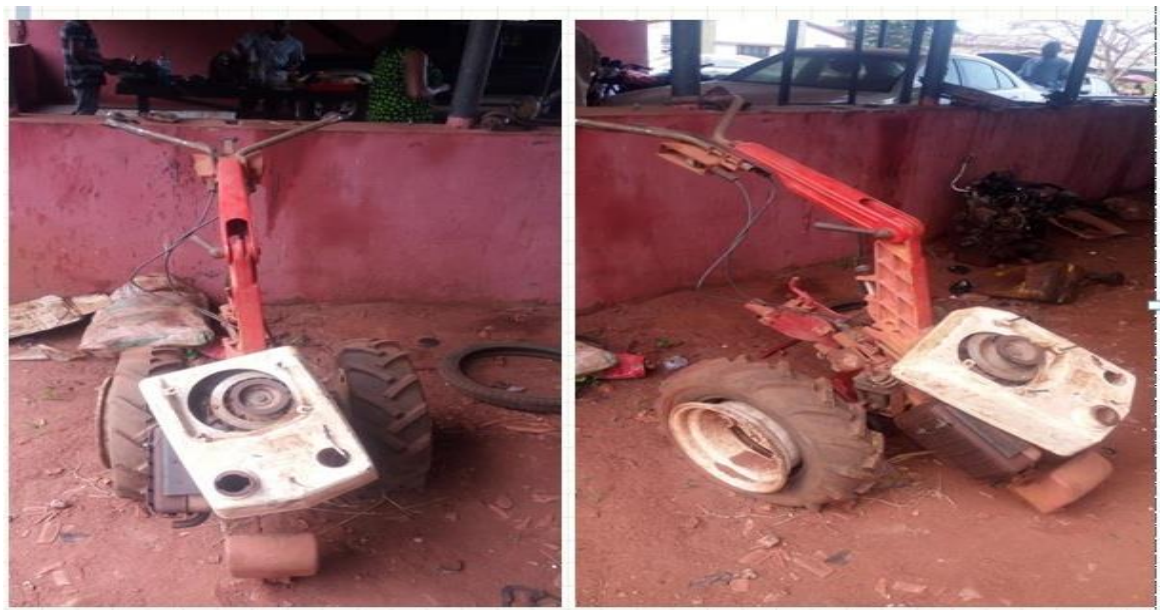

Figure 9: Dilapidated two-wheeled tractor 
The parameters measured and determined for each case included; area of land covered, average time of operation, delay and other interruptions, fuel consumption, the width of action, the average depth of cut, wheel slippage, the speed of operation, field capacity and field efficiency.

\subsection{Refurbishment Analysis}

The tractor refurbishment involves loosening and fixing of replaced and repaired parts using spanners, screwdrivers and pliers. Designing and fabrication of the coupling flange were also done during refurbishment.

Field Operation was carried out with moldboard plow coupled to the refurbished two-wheeled tractor. The implement was coupled to the power tiller and then used to carry out the tillage operation.

Field performance evaluation involves the measurement and determination of field parameters Area of land (ha): Area of land covered was calculated using the length and width measured with the help of measuring tape.

\subsubsection{Machine speed of operations}

The speed of operation for power tiller was measured in kilometers per hour. Ten measurements of the times it took the power tiller to travel along the field row length during an operation was taken and averaged. Using the average of these measurements, the timedistance relationship was converted to kilometers per hour as reported by [21].

$$
\text { Speed }=\frac{\text { Distance }}{\text { Time }} \quad(\mathrm{km} / \mathrm{hr})
$$

\subsubsection{Time of operation ( $\mathrm{hr} / \mathrm{ha}$ )}

Time of operation was estimated using a stop watch. Fuel consumption (L/ha): Fuel consumption was determined by filling the fuel tank to the brim at the onset of the operation, then at the end, the tank was refilled using a graduated cylinder to note the quantity used to refill. This quantity is taken as the amount of fuel consumed for that particular operation [22].

\subsubsection{Soil moisture content}

Soil samples were taken before and from the freshly plowed field immediately after an operation and were placed in sample dish provided with air-tight covers. The airtight sample dish covers were immediately weighed in the field with an accurate weighing balance and later taken to the laboratory for oven drying at $110^{\circ} \mathrm{C}$ for 24 hours as reported by Pollard and Morris [23]. The loss of weight after drying divided by the original weight of individual soil sample multiplied by hundred determines the moisture content (MC) of the soil samples on the dry basis as:

$$
\mathrm{MC}=\frac{\mathrm{Mw}-\mathrm{Md}}{\mathrm{Md}} \times 100
$$

where: $M_{w}$ is the Mass of soil sample before drying ( $g$ ) and $M_{d}$ is the Mass of soil sample after drying (g)

\subsubsection{The depth of cut (m)}

Depth of cut was determined by placing a straight wood across the cut area, ensuring that the two ends of the wood were placed at the top of the original level of the uncut soil surfaces. Then a graduated rule was placed vertically at the Centre of the cut area and where the wood crosses the rule gives the depth of cut for that particular spot [22].

\subsubsection{The width of cut (m)}

Width of cut was determined by placing a straight wood across the cut area, ensuring that the two ends of the wood were placed at the top of the original level of the uncut soil surfaces. Then a graduated rule was used to measure the length of the straight wood placed along the cut [22].

\subsubsection{Wheel slip}

Wheel slip was determined using the following expression as reported by Ademiluyi et al, [22].

$$
\text { Wheel Slip }=1-\frac{\mathrm{V}_{\mathrm{a}}}{\mathrm{V}_{\mathrm{t}}}
$$

where, $\mathrm{V}_{\mathrm{a}}=$ velocity of the tractor when implement is in contact with the soil (loaded scenario); $V_{t}=$ velocity of the tractor when the implement is not engaged with the soil (no load scenario)

\subsubsection{Effective/actual field capacity}

The capacitive performance of an agricultural machine measure the field area covered per unit of time. This capacity performance termed effective field capacity (C) in ha/h was given by Srivastava et al [24] as shown below.

$$
\mathrm{C}=\left(\mathrm{T}_{c}\right) \times \mathrm{e}=\frac{\text { Swe }}{10}
$$

where Tc is the theoretical field capacity (ha/h), S is the field speed $(\mathrm{km} / \mathrm{h})$, w is the Machine width $(\mathrm{m})$ and e is the field efficiency (decimal).

\subsubsection{Field Efficiency}

Field Efficiency (FE) was calculated as follows:

$$
\mathrm{FE}=\frac{\mathrm{C}}{\mathrm{Tc}}
$$




\subsubsection{Implement Draft}

Implement draft requirement was estimated as follows as recorded by Sayed et al. [17]:

$$
D i=F i\left(A+B v+C v^{2}\right) w d
$$

where: $\mathrm{Di}$ is the Implement draft, $\mathrm{KN}, \mathrm{Fi}$ is the dimensionless texture adjustment factor, $\mathrm{i}$ is the 1 for fine, 2 for medium, or 3 for coarse textured soils, A, B, and $C$ is the implement-specific constants, $d$ is the tillage depth, $\mathrm{cm} . \mathrm{w}=$ width of implement $(\mathrm{cm})$, and $\mathrm{v}$ is the field speed $(\mathrm{km} / \mathrm{hr})$. Fi is the dimensionless texture adjustment factor; A, B, C are implements specific constants were adapted from Srivastava et al [24]. Drawbar power was estimated as follows as recorded by Shrida [1]:

$$
\mathrm{Pdb}=\frac{\mathrm{DiV}}{3.6}
$$

where: $\mathrm{P}_{\mathrm{db}}$ is the drawbar power, $\mathrm{kW}$, and $\mathrm{V}$ is the travel speed, $\mathrm{km} / \mathrm{h}$

$$
\mathrm{V}=\frac{\text { average distance }}{\text { total operating time }}
$$

\section{RESULTS AND DISCUSSIONS}

The refurbished tractor being used in the experimental site is shown in Figure 10.
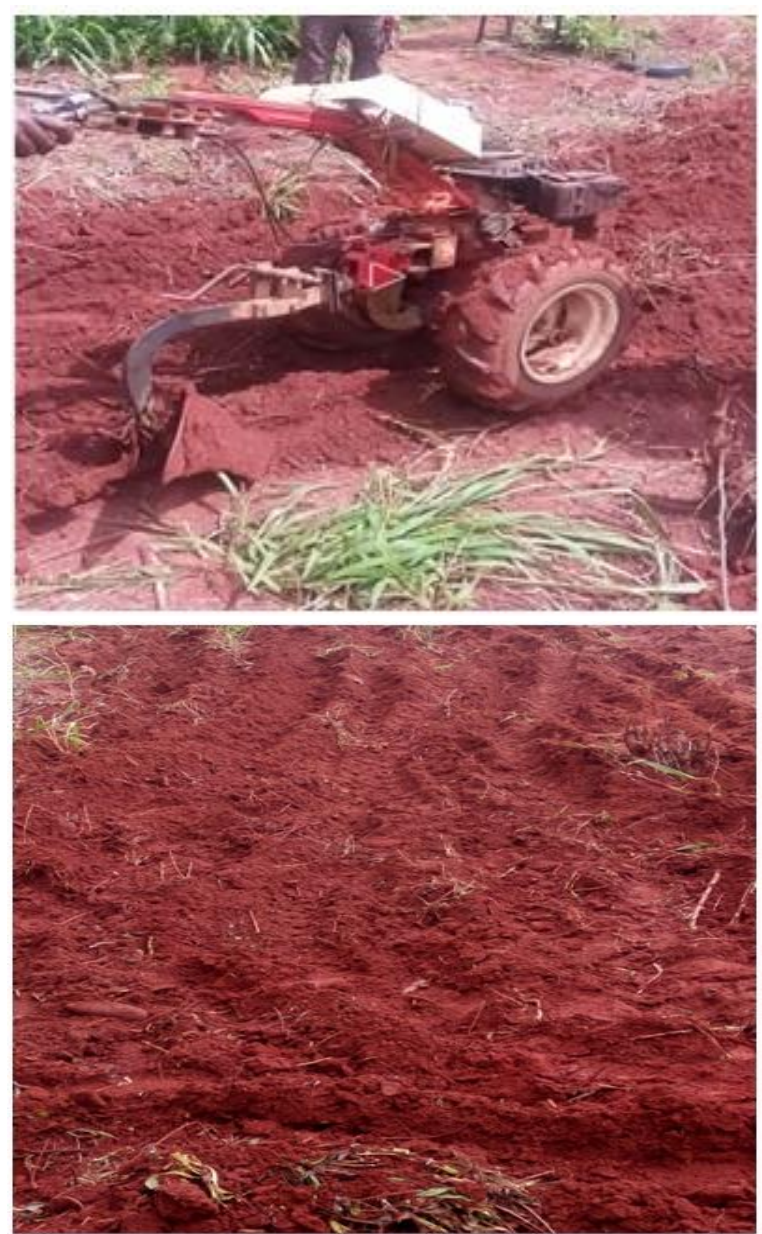

Figure 10: Field testing operation with the refurbished two-wheel tractor.

\subsection{Calculated Parameters}

\subsubsection{Working Speed}

Speed was estimated to be $1.38 \mathrm{~km} / \mathrm{hr}$ using equation (1) stated earlier which is within the designed speed range of $(0.5-1.4 \mathrm{~km} / \mathrm{hr})$ as reported by Singh and Vasta [25]. The parameters are: Row distance $=0.0795 \mathrm{~km}$ Average time $=0.0575 \mathrm{hr}$. On another hand, the speed of operation is $0.77 \mathrm{~km} / \mathrm{hr}$ and $1.1 \mathrm{~km} / \mathrm{hr}$ by Ademiluyi et al. [22] and Adamu et al [26] respectively.

\subsubsection{Effective width and depth of cut}

The effective width of cut was found to be $0.27 \mathrm{~m}$ and effective depth of cut was found to be $0.09 \mathrm{~m}$. Moreover, the width and depth of cut are $0.8 \mathrm{~m}$ and $0.09 \mathrm{~m}$ respectively by Adamu et al [26] and $0.4 \mathrm{~m}$ and $0.2 \mathrm{~m}$ respectively by Ademiluyi et al [22]. The depth of cut and width of implement is shown in Table 1.

Table 1: Depth and Width of cut

\begin{tabular}{ccc}
\hline S/N & Depth of cut $(\mathrm{cm})$ & Width of cut $(\mathrm{cm})$ \\
\hline 1 & 8 & 30 \\
2 & 8.4 & 25 \\
3 & 9 & 28 \\
4 & 9.3 & 27.4 \\
5 & 10 & 26.9 \\
\hline Average & $8.94 \pm 0.779$ & $27.46 \pm 1.81$ \\
\hline
\end{tabular}

\subsubsection{Effective operating time}

Effective operating time was found to be $0.095 \mathrm{hr} / \mathrm{ha}$. On another hand, the effective operating time was stated as $35.65 \mathrm{hr} / \mathrm{ha}$ by [22].

\subsubsection{Delay and other interruptions}

Delay and other interruptions was found to be $0.02 \mathrm{hr} / \mathrm{ha}$

\subsubsection{Wheel slip}

Wheel slip was estimated to be 0.35 using equation (2) stated earlier Where, $\mathrm{V}_{\mathrm{a}}$ is the $1.38 \mathrm{~km} / \mathrm{hr}$ and $\mathrm{V}_{\mathrm{t}}$ is the $2.12 \mathrm{~km} / \mathrm{hr}$

\subsubsection{Fuel consumption}

Fuel consumption was found to be $0.425 \mathrm{~L} / \mathrm{hr}$ which is below the designed fuel consumption of $1.0 \mathrm{~L} / \mathrm{hr}$. On the other hand, the fuel consumptions are $32.90 \mathrm{~L} / \mathrm{hr}$ and $1.3 \mathrm{~L} / \mathrm{hr}$ for $5.3 \mathrm{~kW}$ two-wheeled according to Ademiluyi et al [22] and Adamu et al [26] respectively.

\subsubsection{Effective field capacity}

The effective field capacity was estimated to be 0.032 $\mathrm{ha} / \mathrm{hr}$ using equation (4) stated earlier which is below 
the theoretical effective field capacity of $0.052 \mathrm{ha} / \mathrm{hr}$ which might be due to the nature of the soil and the skill of the Operator, where, $\mathrm{S}=1.38 \mathrm{~km} / \mathrm{h} . \mathrm{w}=0.27 \mathrm{~m}$, $\mathrm{e}=61.5 \%$.

The result obtained was in line with the effective field capacity of $0.0279 \mathrm{ha} / \mathrm{hr}$ and $0.04 \mathrm{ha} / \mathrm{hr}$ according to Ademiluyi et al [22] and Adamu et al [26] respectively. Theoretical field capacity: Theoretical field capacity was estimate to be $0.052 \mathrm{ha} / \mathrm{hr}$ using the same formula and values stated in equation (4) earlier, except that the field efficiency is equal to 1.0 because theoretical field capacity is achieved when the machine is using $100 \%$ of its width without interruption for turns or other idle time.

\subsubsection{Field efficiency}

Field efficiency was estimated to be $61.5 \%$ which is within the range of field efficiency of 50-70\% as reported by Singh and Vasta [25] using equation (5) stated earlier. The parameters are: Tc $=0.032 \mathrm{ha} / \mathrm{hr}$ and $\mathrm{C}=0.052 \mathrm{ha} / \mathrm{hr}$. On another hand, the field efficiencies are $88.30 \%$ and $47 \%$ by Ademiluyi et al [22] and Adamu et al [26].

\subsubsection{Implement Draft}

The implement draft was estimated to be $1.13 \mathrm{kN}$ using the equation (6) stated earlier, where; $\mathrm{Fi}=0.70$ (the soil a medium soil), A, B, C $=652,0.0,5.1$ (a moldboard plow was used), $d=9 \mathrm{~cm}, \mathrm{w}=0.27 \mathrm{~m}$ and $\mathrm{V}=$ $1.38 \mathrm{~km} / \mathrm{hr}$

\subsubsection{Drawbar Power}

The drawbar power of the tractor was estimated to be $0.43 \mathrm{kw}$ using equation (7) stated earlier; where,

$\mathrm{Di}=1.13 \mathrm{KN}$ and $\mathrm{V}=1.38 \mathrm{~km} / \mathrm{hr}$

Table 2: Performance of two-wheeled tractor during plowing operation

\begin{tabular}{ll}
\hline Parameter & Average \\
\hline Effective width of action $(\mathrm{m})$ & 0.27 \\
Effective depth of cut $(\mathrm{m})$ & 0.089 \\
Speed of operation $(\mathrm{km} / \mathrm{hr})$ & 1.38 \\
Effective operation time (hr/ha) & 0.095 \\
Delay and other interruptions (hr/ha) & 0.02 \\
Wheel slip & 0.35 \\
Theoretical field capacity $(\mathrm{ha} / \mathrm{hr})$ & 0.052 \\
Effective field capacity $(\mathrm{ha} / \mathrm{hr})$ & 0.032 \\
Field efficiency $(\%)$ & 61.50 \\
Fuel consumption $(\mathrm{L} / \mathrm{hr})$ & 0.43 \\
Rated power $(\mathrm{kW} / \mathrm{hr})$ & 4.00 \\
Implement draft $(\mathrm{kN})$ & 1.13 \\
Drawbar power $(\mathrm{kW})$ & 0.43 \\
\hline
\end{tabular}

\subsubsection{Soil moisture content}

The soil moisture content before and after field operation was $13.4 \%$ and $13.0 \%$ respectively using equation (2) stated earlier; Before field operation, where $\mathrm{W}_{\mathrm{w}}=183.9 \mathrm{~g}, \mathrm{~W}_{\mathrm{d}}=162.1 \mathrm{~g}$, After field operation, Where $\mathrm{W}_{\mathrm{w}}=184.6 \mathrm{~g}, \mathrm{~W}_{\mathrm{d}}=163.4 \mathrm{~g}$. The summary of the results are presented in Table 2.

\section{CONCLUSION}

1. In accordance with the objectives of this study, the two-wheeled tractor has been refurbished to a better working state.

2. Moreover, the field performance evaluation carried out on the two- wheeled tractor show that, power tillers as they are commonly called stands to be alternative to crude tools and animal drawn equipment. They can be used to execute several agricultural field operations ranging from tillage, to planting, harvesting, and transportation. Power tillers are considered as the appropriate alternative for most small holder farmers in developing countries like Nigeria, given their common average size of farm (fragmented farmlands) and economic situation. It is also been accepted as true that the performance of the power tillers may vary considerably on the positive side with increasing adoption and mastery of use by owners, operators and mechanics. Mass acceptance of the two-wheeled tractor will surely lead to the local manufacture of most components giving rise to employment opportunities to many people. Fuel consumption of the two-wheeled tractor was determined to be $0.425 \mathrm{~L} / \mathrm{hr}$, which was lower than the designed fuel consumption of the tractor of $1.0 \mathrm{~L} / \mathrm{hr}$ thereby, minimizing the cost of operation.

3. Finally, the two wheeled tractor when compared with other two wheeled tractor shows an appropriate field efficiency and field capacity. Also, the fuel consumption of the tractor was considerably lower when compared with other two-wheeled tractor.

\section{REFERENCES}

[1] Shridar, B., P. K. Padmanathan, and R. Manian. 'Utilization Pattern of Power Tillers in Tamil Nadu.' Agricultural Mechanization in Asia, Africa \& Latin America 37(1): 85-89, 2006.

[2] Arturo Lara-Lopez, Chancellor, W. J., Kepner, R. A., Kaminaka, M. S., A Two-wheeled Tractor for manufacture in Mexico. Transactions of ASAE Vol. 25(5): 1189-1194, 1982.

[3] Ademiluyi, S., Oladele, O. I. and Wakatsuki, T. Socioeconomic factors influencing power tiller 
use among Sawah farmers in Bida, Nigeria. Journal of Food, Agriculture \& Environment Finland, 6(3\&4): 387-390, 2008.

[4] Sakai J. Principles of Walking Tractor Plowing and Design Theories of Japanese Plows, J. JSAM Kyushu Section (30), 38-46, 1990.

[5] Witney, B. Choosing and Using Farm Machines. Edinburgh, Land Technology Ltd, pp. 412, 1988.

[6] Ericson, M.. 'Two-Wheel Tractors: Road Safety Issues in Laos and Cambodia.' Safety Science 48(5): 537-43, 2010.

[7] Starkey, Paul, Simon Ellis, John Hine, and Anna Ternell..Improving Rural Mobility: Options for Developing Motorized and Non-motorized Transport in Rural Areas. World Bank Technical Papers No 525. Washington, World Bank, 2002.

[8] Tiwari, P. S., and L. P. Gite.. 'Evaluation of WorkRest Schedules During Operation of a Rotary Power Tiller.' International Journal of Industrial Ergonomics 36(3): 203-10, 2006.

[9] F.A.O. Production year Book - Food and Agriculture Organization of the United Nations, Rome 1980.

[10] Yohanna, J. K. and Ifem, J. L. Performance Evaluation of Field Efficiencies of Farm Machinery in Nigeria. A Case Study of Nasarawa and Plateau States Unpublished M. Eng. Thesis, Department of Agricultural Technology, College of Agriculture, and University of Agriculture Makurdi, Nigeria: 88, 2009.

[11] Kalu R. N. and Egbo C.O. Introduction to Agricultural Mechanization. Macmillan, pp 2 - 6, 1985.

[12] Kathirvel, K.; Manian R. and Balasubramanian M.. Tractive Performance of Power Tiller tyres. Agricultural Mechanization in Asia, African and Latin America. 32 (2):32-36, 2001.

[13] Johansen, C. J.; Haque, M. E.; Bell, R. W.; Thierfelder, C.; Esdaile, R. J. Conservation agriculture for small holder rain-fed farming: Opportunities and constraints of new mechanized seeding systems. Field Crop. Res. 132, 18-32, 2012.

[14] Zoz, F. M. and Grisso R. D. Traction and Tractor Performance, ASAE Distinguished Lecture Series \#27, ASAE Publication Number 913C0403. Paper presented at Agricultural Equipment Technology Conference held at Louisville, Kentucky, USA, 2003.

[15] Zoz F. M.; Turner, R. L. and Shell L. R. Power Delivery Efficiency: A Valid Measure of Belt and tire Tractor Performance. Transactions of the ASAE 45 (3): 509 - 518. 97, 2002.

[16] Abubakar, M. S., Ahmad, D., Othman, J., and Suleiman, S. Present State of Research on
Development of a High Clearance Vehicle for Paddy Fields. Research Journal of Agriculture and Biological Sciences, 5(4): 489 - 497, 2009.

[17] Sayed. C, Chokri.T, Jan. P, Reinhart .V. Motorization and Small Vegetable Farms in the Tunisian Sahel: Performance and soil preparation costs. New Medit N. 2, 2006.

[18] Ayoade A. R. and Adetunbi S.I. Impact of Mechanized Farming on Agricultural Production: An Implication for Poverty Alleviation in Afijio Local Government Area of Oyo State, Nigeria, International Journal of Agriculture Innovations and Research, Volume 1, Issue 4, ISSN (Online) 2319-147, 2013.

[19] Haque, M. E.; Bell, R.W. Development of machinery for smallholders in South and South East Asia. In Presented in Workshop on Modern Conservation Farming Systems and CIMMYT Science Week, Lanzhou, China, 2015.

[20] Haque, M.E.; Bell, R. W.; Islam, M. A.; Rahman, M. A.. Minimum tillage unpuddled transplanting: An alternative crop establishment strategy for rice in conservation agriculture cropping systems. Field Crop. Res. 185, 31-39, 2016.

[21] O'Sullivan, M.F. and Simota, C. Modeling the environmental impacts of soil compaction: a review. Soil Tillage Research, 35(1-2), Pp 69-84, 1995.

[22] Ademiluyi Y. S., Ozoemenani A, Ugwuishiwu B. O., Oyelade 0. A. Performance assessment of twowheel tractor on a loamy sand soil of Ilorin. Nigerian Journal of Technology, Vol. 26 no.1. Pg 59-66, 2007.

[23] Pollard, S. and J. Morris. "Economic aspects of the introduction of small tractors in developing countries towards a Philosophy for small tractor development." Paper presented at the Spring National Conference of the IAE at NCAE, Silsoe, Bedford, 1978.

[24] Srivastava, A. K., Carroll, E. G., Roger, P. R., and Dennis, R. B. Machine Selection and management. Chapter 15, Pg 530-531, in Engineering Principles of Agricultural Machines, $2^{\text {nd }}$ ed., St. Joseph, Michiga, USA (ASABE) 2006.

[25] Singh, D. K. and Vasta, S. P. Development of Tools and Implements to reduce Drudgery of Women in Hill Agriculture. A Journal of Agriculture and Rural Development in the Tropics and Subtropics Himachal Pradesh Agricultural University Palampur, India. 1998.

[26] Adamu F. A, Jahun B. G and Babangida B. Performance Evaluation of power tiller in Bauchi state Nigeria. Journal of Biology, Agricultural and Healthcare, vol. 4, No 9. Pg. 60-69, 2014. 